\title{
Rare thyroid diseases
}

\author{
Katarzyna Łącka \\ From 4th Congress of the Polish Thyroid Association 2013 \\ Lodz, Poland. 11-13 April 2013
}

In general, rare thyroid diseases can be divided into neoplastic and non-neoplastic.

Neoplastic rare thyroid diseases include the following:

1. primary thyroid lymphoma (1-5\% all malignant neoplasms of the thyroid; 2:1 000000 per year);

2. metastases to the thyroid gland (2-3\% malignant thyroid neoplasms; $0.5-2.8 \%$ in autopsy) from various primary cancers such as breast carcinoma, renal carcinoma, colon carcinoma, melanoma and others;

3. others (ie: sarcoma).

On the contrary, non-neoplastic rare thyroid diseases include the following:

1. congenital defects of thyroxine binding proteins, particularly partial and total congenital TBG deficiency (1:5 000), congenital TBG excess (1: 25000 ) (both caused by $T B G$ gene mutations) and familial dysalbuminemic hyperthyroxinemia (1:25 000, more frequent in some populations, such as the Spanish and Portuguese);

2. congenital resistance to thyroid hormones (with frequency about 1:40 000) as a result of THRB gene mutations;

3. rare cases of congenital thyroid hormones biosynthesis defects, for instance: Pendred syndrome (with frequency of 7.5-10:100 000) resulting from PDS gene mutations, total iodide organification defects (1:66 000; $T P O$ and THOX2 gene mutations);

4. congenital defects of the thyroid gland development, which constitute about $85-90 \%$ causes of primary congenital hypothyroidism. About $2 \%$ of these are associated with the presence of other nonthyroid congenital anomalies and are caused by genetic mutations: for example, in the PAX, TTF1, TTF2, GNAS 1 genes;

5. congenital nonautoimmune hyperthyroidism as a result of TSH receptor gene mutation (TSHR) (until now 55 various mutations and over a dozen cases of de novo germinal mutations have been described);

\footnotetext{
Department of Endocrinology, Metabolism and Internal Medicine, Poznan
} University of Medical Science, Poznan, Poland
6. hyperthyroidism associated with McCune-Albright syndrome (in about $30 \%$ of patients with this syndrome; McCune-Albright syndrome frequency of occurrence is estimated - 1:10 000-1:1 000 000; background - mutation in the GNAS 1 gene);

7. an association of the thyroid autonomous nodule and Graves' disease (4.1\%), and the thyroid cancer and Graves' disease (1.1\%-6.5\%).

The latest data on the etiopathogenesis of rare thyroid diseases, diagnostic criteria and possibilities for their treatment will be discussed. In addition, information obtained from PUBMED database concerning patients with rare thyroid diseases detected in the Polish population, particularly the data on molecular-genetic results, will be presented.

Published: 5 April 2013

doi:10.1186/1756-6614-6-S2-A36

Cite this article as: Łącka: Rare thyroid diseases. Thyroid Research 2013 6(Suppl 2):A36.
Submit your next manuscript to BioMed Central and take full advantage of:

- Convenient online submission

- Thorough peer review

- No space constraints or color figure charges

- Immediate publication on acceptance

- Inclusion in PubMed, CAS, Scopus and Google Scholar

- Research which is freely available for redistribution
() Bïomed Central
C Biomed Central

(c) 2013 Łącka; licensee BioMed Central Ltd. This is an Open Access article distributed under the terms of the Creative Commons Attribution License (http://creativecommons.org/licenses/by/2.0), which permits unrestricted use, distribution, and reproduction in any medium, provided the original work is properly cited. 